\title{
Study on the yeast and mould biota of the botrytized grapes in Tokaj region in two years ${ }^{1}$
}

\author{
Bene, Zs. and Magyar, I. \\ Szent István University, Faculty of Food Sciences, Department of Oenology, Budapest
}

\begin{abstract}
Summary: The famous wine Tokaji Aszú is produced from "noble rotted" grapes infected and modified by Botrytis cinerea under special condition. The objective of this study was quantitative and qualitative characterisation of saprophytic fungi present on the surface of aszúberries, with special regard to yeasts. There were considerable differences in these populations depending on the origin of noble rotted berries, notably between berries taken from the vine or the ones taken from the winery. Beside Botrytis, other mould species like Penicillium, Aspergillus were commonly found, in widely varying population. Yeast counts were detected between $10^{4}$ and $10^{7}$ cfu/g berry. In the samples taken from the vineyard Candida pulcherrima predominated followed by some aerobic basidiomycetous species, but Hanseniaspora species were also present in relatively high population. After transport and storage of the grape in the wineries, population of aerobic yeasts and $C$. pulcherrima quickly declined and Candida stellata followed by other sugar tolerant species became dominant. This autoselection process directs attention to the importance of storage conditions.
\end{abstract}

Key words: Botrytis, noble rot, Tokaji, yeast

\section{Introduction}

Produced from "noble rotted" grapes, Tokaji Aszú is known as one of the oldest botrytized wines all over the world. Climatic conditions, soil circumstances and grapevarieties of Tokaj-region offer exceptionally favourable parameters to the formation of noble rot caused by Botrytis cinerea. Noble rotted grapes - locally called "aszú" berries are the result of the special metabolic activity of Botrytis which can occur when there is an alternation of short damp periods and longer sunny days after the time when berries reached the whole maturity state. Under these conditions the contamination of mould takes plece by penetration of the germinating conidia and hyphae of Botrytis into the berry through microfissures of the visually intact skin. After infection the numerous destructive enzymes of mould start to cause chemical changes. Firstly the degradation of cell walls is realised, which causes cell death and the colour of skin turns into chocolate or greyish blue. In sunny days berries lose much water through the penetration cracks. Since it cannot be replaced from the vine through stem at the whole maturity state, the juice can be strongly concentrated by drying. As a common results of the enzymatic activity of Botrytis and the physical process of concentration the grapes undergo complex chemical modifications, which have been well studied (reviewed by Dittrich, 1987, Doneche, 1993). Also the aromatic compounds like free terpenoids go through considerable changes and new volatile compounds are produced (Kerényi, 1976).
Infection of Botrytis opens free way for other microorganisms such as other mould species (like Penicillium, Aspergillus) and yeasts. These microorganisms cannot penetrate into the berries unless hurt of the berry-skin takes place. This kind of injuries can be caused by Botrytis giving possibility to the concomitant microbiota for infection. Presence of other mould strains can cause formation of unpleasant flavour and smell. Yeast species invading the disrupted berry skin may, however, have either positive or negative impact on the quality of aszú wine during the special vinification process which includes storage of the aszú grapes, maceration of the berries with determined quantity of must or wine, re-fermentation of the mixture (mainly spontaneously) and long ageing of wine in small oak barrels. Among these steps, fermentation is the most critical one because of the extreme composition of wine and possibly because of the special composition of the indigenous yeast biota.

Microbiota of botrytized grapes and wines from different countries have been studied by several authors (Domerque, 1957, Minarik, 1963, Le Roux et al., 1973,) but there are few studies published relating to the Hungarian Tokaj wine district (Magyar, 1996, Kalmár et al., 1999).

In this work we have studied the microbiological features of aszú-berries from Tokaj-region, and we have made steps to identify the representative yeast species present on the surface of botrytized berries. The results from two vintages are presented here, of which the drier year 1999 provided better conditions for the noble rot than the year 1998 .

\footnotetext{
1 This work was supported by the research project OM FKFP 0096/1999 of the Ministry of Education, Hungary.
} 
To establish a better control of Aszú fermentation, decper knowledge is inevitable concerning the storage circumstances of noble rotted berries, too. We examined surface of berries taken from the vine-stock directly and also from the winery, after several weeks of storage. We paid attention to the change of yeast and mould populations as a function of origin and years.

\section{Material and method}

Samples of aszú-berries were taken aseptically partly from the vineyards, partly from the storage place of various winemaking companies. Cells attached to the surface of aszúberries were washed into sterile water with shaking, then after diluting they were spread-plated on different selective media. The total yeast and mould count was determined in complex nutritive medium YEPD (yeast extract $1 \%$, peptone $0.5 \%$, glucose $2 \%$ ), $\mathrm{pH} 3.5$, and in many cases also in Dichloran-Rose-Bengal-Chloramphenicol agar (Merck) which restricts the colony size of several moulds. The lower detection limit of the method was about $10^{2} \mathrm{cfu} / \mathrm{g}$ berry.

Means of the logarithmic cell counts obtained from different sampling places were statistically compared by t-probe (unequal number of observations with homogenous variances).

The characteristic yeast colonies were isolated from several dilution levels, purified by serial streaking, investigated microscopically then identified according to Kurtzmann \& Fell (1998). The classic morphological (colour in different media, type of vegetative reproduction, sporulation and conjugation on McClary-acetate agar, malt extract agar, pseudomycelium formation on corn meal agar) and physiological (fermentation, multiplication at $37^{\circ} \mathrm{C}$, urease-test, assimilation of galactose, sucrose, maltose, xylose, raffinose, mannitol, erithritol, lactose, cellobiose, melibiose, ethyl-amine, lysine, nitrate) examinations served as basis of the identification. All strains were identified to the level of genera and most of them to the level of species.

\section{A, Aszú berries from the vine}

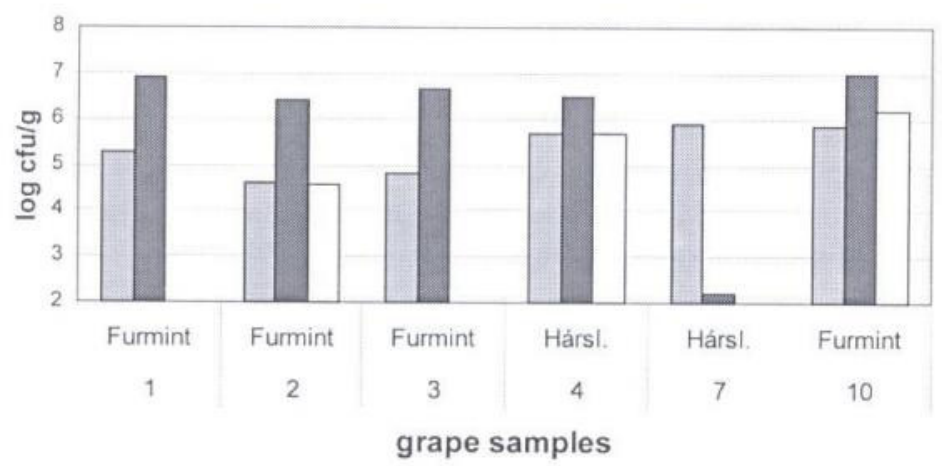

$\square$ Total yeast $\square$ Botrytis $\square$ Other moulds
Moulds were identified to the level of genera according to the morphological stamps.

\section{Results \\ Quantitative composition of microorganisms on the surface of aszú - berries}

Figure $/$ displays the main results of our studies in 1998 , Figure 2 shows the composition of examined aszú-berries in 1999. Mean values of the measured populations with some statistical parameters are summarised in Table $l$. In the quantitative composition of microbiota considerable differences were found depending on the place of sampling-, notably between berries taken from the vine directly and those taken from the cellars (Table I).

\section{Moulds}

In the vineyard as expected, the order of magnitude of mould-population was significantly higher, than those commonly found in sound grapes. It has to be noted that, as a consequence of surface washing method, the published mould-counts actually mean conidia-counts on the surface of examined berries, which is not necessarily proportional with the mass of mycelium spread through skin.

Botrytis conidia were present in comparable density in both years in the samples from the vineyards (mean logarithmic values 5.9 and $5.7 \mathrm{cfu} / \mathrm{g}$ ), although the variances of the samples were very high (Table 1). Other mould species like Penicillium, Aspergillus were measured at much lower average population (mean value: 3.7 ), with individual data from the detection limit to $10^{6} \mathrm{cfu} / \mathrm{g}$ counts.

After 2-3 weeks of storage no significant changes were detected in the conidia count of either Botrytis or other moulds in 1998, but large reduction was found in both populations in the drier year 1999 that produced higher quality aszú grapes. This must be a consequence of higher sugar content of the grapes.

\section{B, Aszú berries from the winery}

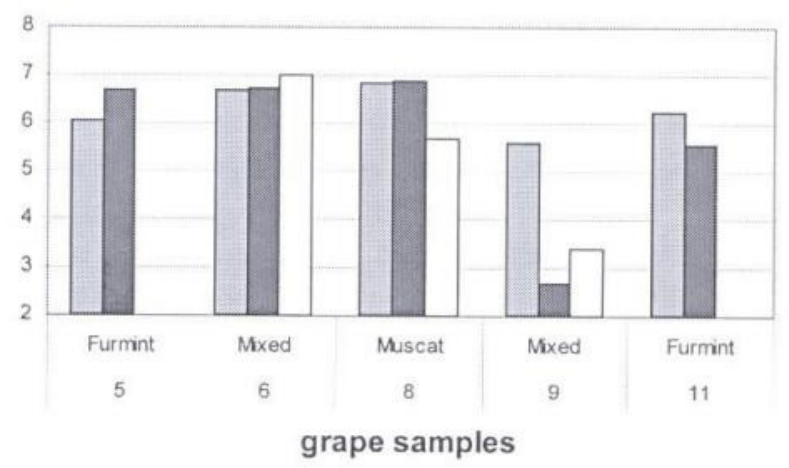

Total yeast $\square$ Botrytis $\square$ Other moulds

Figure I Yeast and mould counts on the surface of noble rotted grapes taken from the vine before harvest (A) and from the winery after storage (B) in the year 1998. 


\section{A, Aszú berries from the vine}

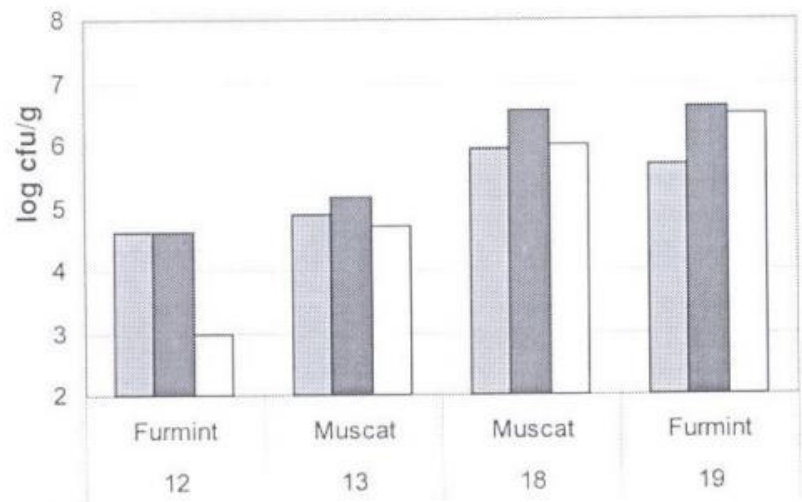

Total yeast $\square$ Botrytis $\square$ Other moulds

\section{B, Aszú berries from the winery}

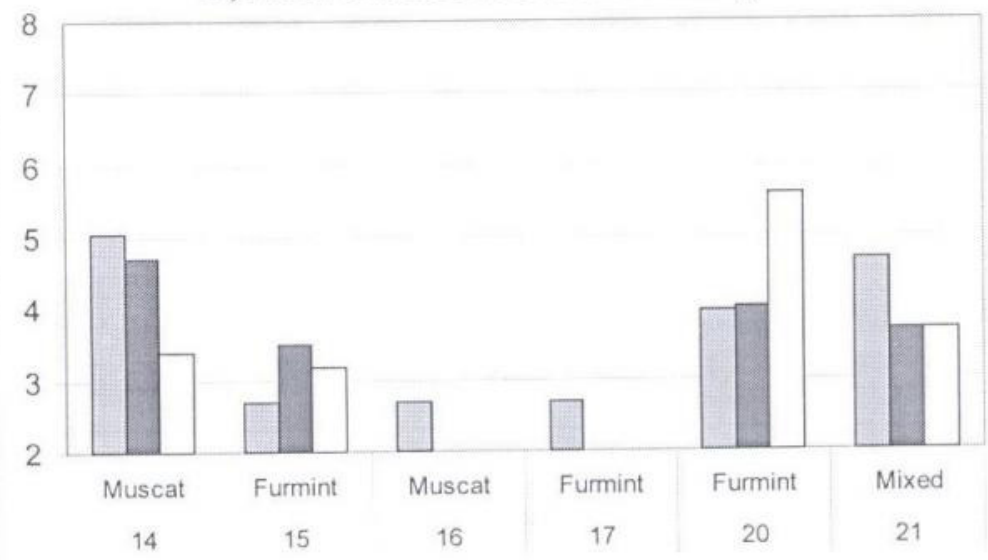

$\square$ Total yeast $\square$ Botrytis $\square$ Other moulds

Figure 2 Yeast and mould counts on the surface of noble rotted grapes taken from the vine before harvest (A) and from the winery after storage (B) in the year 1999.

Table I Comparison of the mean values of cell counts ( $\log \mathrm{cfu} / \mathrm{g}$ ) detected on the surface of aszú grapes taken from different sampling places (vineyard or winery) in two years.

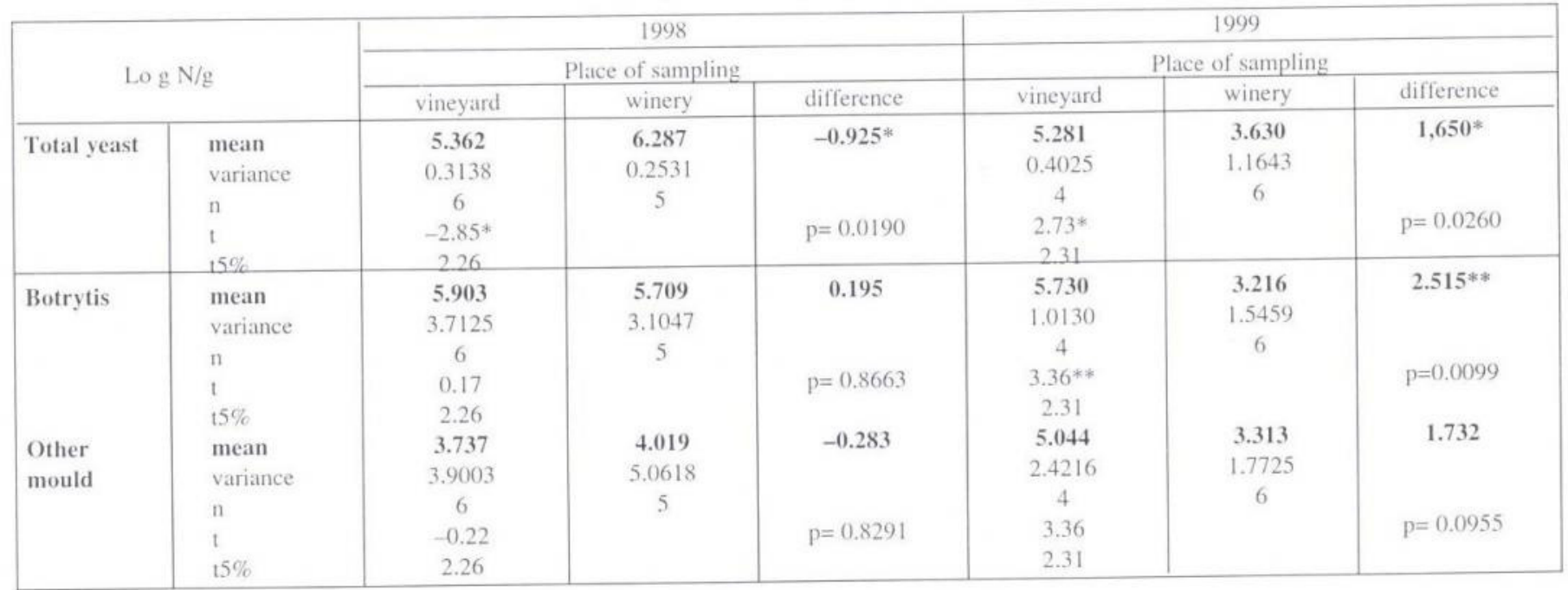

$\mathrm{n}=$ number of samples

$\mathrm{t}=$ calculated $\mathrm{t}$-value

$\mathrm{t} 5 \%=$ critical $\mathrm{t}$-value at $\mathrm{p}=0.05$

$\mathrm{p}=$ significance level of $\mathrm{t}$-probe. Difference between the mean values is considered significant if $\mathrm{p}<0.05(*)$ and highly significant if $\mathrm{p}<0.01(* *)$.

\section{Yeasts}

The order of magnitude of yeast populations in the samples from vine was similar in the two vintages (mean logarithmic values are 5.36 and 5.21 , respectively) but the samples from the winery showed quite different patterns in the two years. While the conditions of the lower quality aszú grapes supported significant yeast growth on the surface of the aszú berries in 1998, considerable reduction (from 5.28 to $3.63 \mathrm{log} \mathrm{cfu} / \mathrm{g}$ ) could be experienced in 1999 , similarly to the tendency of mould counts. The total yeast population decreased under $10^{4} \mathrm{cfu} / \mathrm{g}$ in the majority of samples. From the results it is clear that circumstances on the surface of higher dry-material berries do not give favourable parameters to the multiplication of yeasts during the storage.

There was no noticeable correlation between yeast counts and grape varieties, although this question should be further investigated in larger number of samples.

\section{Taxonomic composition of the yeast biota of aszú grapes}

In these studies we isolated 75 yeast strains then they were identified according to Kurtzmann \& Fell (1998). Table 2. displays qualitative composition of yeast-biota in both years. The identification was not successful in some cases 
Table 2 Taxonomic composition of the yeast biota detected on the surface of aszú grapes taken from the vine or from the winery, in two years

\begin{tabular}{|c|c|c|c|c|c|c|}
\hline Year & $\begin{array}{l}\text { Place of } \\
\text { sampling }\end{array}$ & $\begin{array}{l}\text { Grape- } \\
\text { variety }\end{array}$ & $\begin{array}{l}\text { Code of } \\
\text { samples }\end{array}$ & $\begin{array}{l}\text { Cell count of the } \\
\text { dominant yeast-strain } \\
(\log \mathrm{cfu} / \mathrm{g})\end{array}$ & Dominant yeast genera or species & Other yeast-species isolated \\
\hline \multirow[t]{2}{*}{1998} & vine-stock & $\begin{array}{l}\text { Furmint } \\
\text { Furmint } \\
\text { Furmint } \\
\text { Furmint } \\
\text { Hárslevelũ } \\
\text { Hárslevelũ }\end{array}$ & $\begin{array}{c}1 \\
2 \\
3 \\
10 \\
4 \\
7\end{array}$ & $\begin{array}{l}5.30 \\
4.60 \\
4.60 \\
5.70 \\
5.48 \\
6.00\end{array}$ & $\begin{array}{l}\text { Hanseniaspora guillermondii } \\
\text { Non-identified } \\
\text { Rhodotorula sp. } \\
\text { Candida pulcherrima } \\
\text { Candida stellata } \\
\text { Non-identified }\end{array}$ & $\begin{array}{l}\text { Rhodotorula sp. } \\
\text { C.pulcherrima, C.apicola } \\
\text { Hanseniaspora uvarum } \\
\text { C.pulcherrima, C.paludigena, } \\
\text { H.uvarum } \\
\text { Zygosacch, sp., C.cantarelli, } \\
\text { C.multigemmis, Kluyv.lactis }\end{array}$ \\
\hline & winery & $\begin{array}{l}\text { Furmint } \\
\text { Mixed } \\
\text { Muscat } \\
\text { Mixed } \\
\text { Furmint }\end{array}$ & $\begin{array}{l}5 \\
6 \\
8 \\
9 \\
11 \\
\end{array}$ & $\begin{array}{l}5.78 \\
6.00 \\
6.30 \\
5.30 \\
5.00 \\
\end{array}$ & $\begin{array}{l}\text { Candida stellata } \\
\text { Hanseniaspora occidentalis } \\
\text { Candida floricola } \\
\text { Zygosaccharomyces rouxii } \\
\text { Brettanomyces bruxellensis }\end{array}$ & $\begin{array}{l}\text { P.angusta, Kluyv,thermotolerans } \\
\text { C.stellata, C.pulcherrima } \\
\text { C.pulcherrima, Rhodotorula sp., } \\
\text { H'spora uvarum, C. sake } \\
\text { Rhodotorula sp., Br.bruxellensis, } \\
\text { H'spora uvarum } \\
\text { Kluyveromyces lactis }\end{array}$ \\
\hline \multirow[t]{2}{*}{1999} & vine-stock & $\begin{array}{l}\text { Furmint } \\
\text { Muscat } \\
\text { Mixed } \\
\text { Furmint }\end{array}$ & $\begin{array}{l}12 \\
13\end{array}$ & $\begin{array}{l}3.90 \\
4.30\end{array}$ & $\begin{array}{l}\text { Cryptococcus albidus } \\
\text { Sporidiobolus pararoseus } \\
\text { Candida pulcherrima } \\
\text { Candida pulcherrima }\end{array}$ & $\begin{array}{l}\text { Cryptococcus macerans, } \\
\text { Sporidiobolus pararoseus } \\
\text { C.pulcherrima, Lalaria sp.. } \\
\text { Arxula terrestris, Cryptococcus } \\
\text { macerans } \\
\text { H'spora uvarum, C. stellata, } \\
\text { Sympodiomycopsis sp. }\end{array}$ \\
\hline & winery & $\begin{array}{l}\text { Muscat } \\
\text { Furmint } \\
\text { Furmint } \\
\text { Mixed }\end{array}$ & $\begin{array}{l}14 \\
15 \\
17 \\
20 \\
21\end{array}$ & $\begin{array}{l}4.00 \\
2.85 \\
2.70 \\
3.78 \\
6.30\end{array}$ & $\begin{array}{l}\text { Candida stellata } \\
\text { Candida stellata } \\
\text { Non-identified } \\
\text { Torulaspora sp. } \\
\text { Candida stellata }\end{array}$ & $\begin{array}{l}\text { Zygosacch. sp. } \\
\text { C. stellata, C. pulcherrima } \\
\text { Torulaspora delbrueckii, } \\
\text { Zygosacch.rouxii }\end{array}$ \\
\hline
\end{tabular}

because the strain died off, and one part of the isolated strains could be determined only to the level of genera.

On the aszú-berries taken from the vineyard directly, the most frequently recognised yeast species was the Candida pulcherrima (teleomorphic state: Metschnikowia pulcherrima) followed by basidiomycetes- related aerobic species like Rhodotorula, Cryptococcus, Sporidiobolus. In the year of 1998 when circumstances were not as favourable as in 1999, Hanseniaspora species could be found in higher frequency, similarly to the surface of non-botrytized grapes.

As opposed to that feature, the taxonomic composition of yeast-flora on the samples taken from wineries is very different. Aerobic yeasts, Hanseniaspora species and the Candida pulcherrima generally disappeared or declined, while the sugar-tolerant Candida stellata was found in high population. Other sugar-tolerant yeasts like Zygosaccharomyces, Torulaspora species with good fermentative skill were enriched, too.

Dominance of these species on noble rotted grapes with special regard to $C$. stellata- had been reported long ago in the wine districts of Gironde (Domerck, 1957) and often associated with the Botrytis infection (Le Roux et al., 1973., Gandini, 1973, Minarik et al., 1978, Heard \& Fleet, 1985). High presence of this species was reported also on the sound grapes in Mediterranean areas and in Australia (Mora et al.,
1988, Martínez et al., 1989, Fleet \& Heard, 1993) but not in cooler winegrowing regions.

In this study dominance of $C$. stellata was found only after the transport and storage of the aszú berries into the wineries. Saccharomyces cerevisiae was not found in the surface of aszú-berries, irrespective of the place of sampling or year.

\section{Conclusions}

According to our study the yeast biota of noble rotted berries is different from that of non-botrytized grapes and it is highly influenced by the storage of the grapes in the wineries before vinification. The effect of year on the yeast biota was also significant, although less pronounced. The results show that during picking, sorting, transport and storing, microbiota of the noble rotted berries undergoes a considerable autoselection process due to the special microecological conditions.

Further research is in progress concerning the qualitydetermining role of the dominant yeasts of aszú grapes with special regard to the importance of Candida stellata. As next steps the optimisation of the storage conditions of Aszú - berries has to be elaborated, too. 


\section{References}

Dittrich, H.H. (1987): Mikrobiologie des Weines, Ulmer, Stuttgart.

Domerque, S. (1957): Étude et classification des levures de vin de la Gironde. Ann. Technol. Agric. 6: 139-183.

Donèche, B J. (1993): Botrytized wines. In: Wine Microbiology and Biotechnology (ed. Fleet H.G.) Harwood Academic Publ., Cheer, Switzerland 327-351.

Fleet, G.H., Lafon-Lafourcade, S. \& Ribeéreau-Gayon, P. (1984): Evolution of yeasts and lactic acid bacteria during fermentation and storage of Bordeaux wines. Appl. Environ. Microbiol, 48: 1034-1038.

Fleet, G. H. \& Heard, G. M.(1993): Yeasts - Growth during fermentation. In: Wine Microbiology and Biotechnology (ed. Fleet H.G.) Harwood Academic Publ., Cheer, Switzerland 327-351.

Heard, G. M. \& Fleet, G.H. (1985): Growth of natural yeast flora during the fermentation of inoculated wines. Appl. Environ. Microbiol, 50: 727-728.

Gandini, A. (1973): Influenza dell' infezione botritica delle uve sulla blastoflora dei mosti e sulla composizione dei vini dolci da questi ottenuti. Vini d' Italia, 82: 27-36.

Kalmár, Z. P., Miklósy, É., Pölös, V. \& Kerényi, Z. (1999): Les effets de la qualité des grains d'aszú et les différents modes de vinification sur la constitution des vins d'aszú de Tokaj-Hegyalja. Oenologie 99. 6e Symposium International d'Oenologie. Proceedings, 191-195.

Kerényi, Z. (1976): Tokaji borkülönlegességek aromaanyagainak gázkromatográfiás vizsgálata. I. Illékony neutrális komponensek GLC-MS analízise. Borgazdaság, 24: 101-107.

Kurtzmann, C.P. \& Fell, J.W. (1998): The Yeasts. A taxonomic study. Fourth Revised and Enlarged Edition. Elsevier Science B.V. USA.

Le Roux, G., Eschenbruch, R. \& De Bruin, S.I. (1973): The microbiology of South African winemaking VIII. Microflora of healthy and Botrytis cinerea infected grapes. Phytophylactica, 5: $51-54$.

Magyar, I. (1996): Study on the yeast flora of Tokaj Wine district. 11 th International Oenological Symposium. Sopron, Hungary. Proceedings, 30-40.

Minárik, E. (1963): Beitrag zur Mikroflora von Ausleseweinen. Mitteilungen Rebe und Wine, 13: 186-188.

Mora, J., Barbas, J. I., Ramis, B. \& Mulet, A. (1988): Yeast microflora associated with some Majorcan musts and wines. Am. J. Enol. Vitic., 39: 344-346.

Martínez, J., Millán, C. \& Ortega, J.M. (1989): Growth of natural flora during the fermentation of inoculated musts from Pedro Ximenez grapes. S. Afr.J.Enol.Vitic., 10: 31-35. 